\title{
Urinary cadmium and lead concentrations and their relation to blood pressure in a population with low exposure
}

\author{
J STAESSEN, ${ }^{1} \mathrm{C}$ J BULPITT,${ }^{2} \mathrm{H}$ ROELS,${ }^{3}$ A BERNARD,${ }^{3}$ R FAGARD,${ }^{1} \mathrm{~J}$ V JOOSSENS,${ }^{4}$ \\ R LAUWERYS,${ }^{3}$ P LIJNEN,${ }^{1}$ AND A AMERY' \\ From the Hypertension and Cardiovascular Rehabilitation Unit, ${ }^{1}$ Department of Pathophysiology, Katholieke \\ Universiteit van Leuven, Leuven, Belgium, Department of Medical Statistics and Epidemiology, ${ }^{2}$ London \\ School of Hygiene and Tropical Medicine, London, UK, Medical and Industrial Toxicology Unit, ${ }^{3}$ \\ Universite Catholique de Louvain, Brussels, Belgium, and School of Public Health, ${ }^{4}$ Department of \\ Epidemiology, Katholieke Universiteit van Leuven, Leuven, Belgium
}

\begin{abstract}
The 24 hour urinary excretion of cadmium (U-Cd) and lead (U-Pb), and the excretion of beta-2-microglobulins and retinol binding protein concentration in spot urines, were determined in a random $4 \%$ sample of the population of a small Belgian town. Blood pressure and body weight were measured on two separate occasions. U-Cd averaged $2.4 \mathrm{nmol} / 24 \mathrm{~h}$ in 46 youths, increased with age, and was significantly higher in 57 adult men as compared with 59 women $(9.3 v 7.2 \mathrm{nmol} / 24 \mathrm{~h} ; \mathrm{p}<0.01)$. U-Pb averaged $28 \mathrm{nmol} / 24 \mathrm{~h}$ in youths and similarly increased with age: adult men excreted more lead than women $(64 v 40.0 \mathrm{nmol} / 24 \mathrm{~h} ; \mathrm{p}<0.001)$. Among men, manual workers excreted more cadmium $(12.6 v 7.5 \mathrm{nmol} / 24 \mathrm{~h} ; \mathrm{p}<0.05)$ but a similar amount of lead $(62 v 61 \mathrm{nmol} / 24 \mathrm{~h})$ compared with office workers. After adjusting for sex and age, $\mathrm{U}-\mathrm{Cd}$ and $\mathrm{U}-\mathrm{Pb}$ were not related to body weight and cigarette consumption. In simple regression analysis, U-Cd was positively correlated with both systolic $(r=+0.30 ; p<0.05)$ and diastolic $(r=+0.38 ; p<0.01)$ blood pressure in women. After adjusting for other contributing variables, however, a weak but negative relation became apparent between systolic pressure and $\mathrm{U}-\mathrm{Cd}$ in women $(t=-2.21 ; \mathrm{p}=0.033)$ and between diastolic pressure and U-Cd in men $(t=-2 \cdot 04 ; \mathrm{p}=0.047)$. In women urinary beta-2-microglobulin was related to diastolic pressure $(\mathrm{r}=-0.44 ; \mathrm{p}<0.01)$ and after adjusting for age to both systolic $(t=-2.75 ; \mathrm{p}=0.009)$ and diastolic $(t=-3.07 ; \mathrm{p}=0.004)$ pressure. In none of the sex-age groups did $\mathrm{U}-\mathrm{Pb}$ and retinol binding protein contribute to the blood pressure variability.
\end{abstract}

Animal experiments have shown that cadmium administration may increase blood pressure (for review see ref 1 ). Schroeder was among the first to suggest that minimal long term cadmium exposure in man might contribute to the development of arterial hypertension. ${ }^{2}$ Several reports have suggested that chronic or low grade lead exposure may be associated with a rise in blood pressure..$^{3-6}$ Nevertheless, the possible role of cadmium and lead in the pathogenesis of hypertension remains controversial, as both affirmative ${ }^{3-15}$ and negative ${ }^{16-24}$ studies have been reported. The purpose of the pre-

Received 15 December 1982

Accepted 14 March 1983 sent study was to determine the urinary excretion of cadmium and lead in a random sample of the households of a small Belgian town and to investigate whether a significant and independent association could be found between blood pressure and the urinary cadmium and lead output.

\section{Methods}

A random sample, consisting of $4 \%$ of all households was identified in a Belgian town with a total population of 9000 inhabitants. After excluding subjects who had recently moved or died, 274 people aged 10 years or more were eligible for the study.

Fourteen teams each of two trained volunteers were recruited. After explanation of the rationale 
and methodology of blood pressure measurements, the volunteers were given experience with the use of a regular sphygmomanometer at home for one week. The volunteers were then tested in two phases: firstly, they recorded the "pressures" from the London School of Hygiene sound film, showing a falling mercury column. If all their readings were within $10 \%$ of the standard they were finally tested using live subjects and stethoscopes with two pairs of ear pieces.

Each household was visited twice by the same team of volunteers. The first home visit consisted of five consecutive blood pressure readings (phase 5 diastolic pressure) obtained with a standard sphygmomanometer in the sitting position, followed by a pulse rate count and a measurement of body weight. A self administered questionnaire and a wide neck, metal free polyethylene container for a 24 hour urine collection were given to the participants, who were carefully instructed to keep these containers closed except when voiding in order to prevent airborne metal contamination. The questionnaire inquired about the participants' medical history and their current and past occupation, smoking habit, and drug intake. At the second visit two to five weeks later, the questionnaire and a recent 24 hour urine sample were collected and the measurement of blood pressure, pulse rate, and body weight repeated. Each subject was thus characterised by the mean of 10 blood pressure measurements and by both determinations of pulse rate and body weight. At the second visit an aliquot of freshly voided urine was immediately transferred to a small polyethylene bottle $(100 \mathrm{ml})$ containing $100 \mu \mathrm{l}$ of a $10 \%$ sodium azide solution.

Before use the containers for the 24 hour urine collections were thoroughly cleansed by bristle and detergent. Thereafter, they were filled with $200 \mathrm{ml}$ of $65 \%$ nitric acid and deionised water up to their total volume of two litres and left for 24 hours. They were then rinsed five times consecutively, again using deionised water, and dried in an oven. Finally, $10 \mathrm{ml}$ acetic acid (99-100\%) and $200 \mathrm{mg}$ thymol were added to the containers which were tightly closed before storage. Before use in the study, a random sample of the prepared containers was checked for cadmium and lead contamination and none was found to be positive. When 24 hour urine samples were returned to the laboratory, an aliquot of $50 \mathrm{ml}$ was transferred to a small container and kept frozen at $-20^{\circ} \mathrm{C}$ until analysed.

The 24 hour urine samples were analysed for cadmium, lead, sodium, potassium, and creatinine. The cadmium and lead concentration in urine were measured as described previously, ${ }^{25}$ using a Perkin-Elmer, Model 305 atomic absorption spec- trophotometer equipped with a deuterium background correction system and a Perkin-Elmer HGA-74 atomiser unit. From the spot urine samples, $\beta_{2}$-microglobulin ${ }^{26}$ and retinol binding protein $^{27}$ were determined, since these light molecular weight proteins are often used to monitor cadmium toxicity ${ }^{28}{ }^{29}: \mathrm{pH}$ and creatinine concentration were also measured in spot urines.

The response rate was $68 \%$ and table 1 shows the

Table 1 Age and sex distribution of responders and non-responders

\begin{tabular}{llllll}
\hline \multirow{2}{*}{ Age (years) } & \multicolumn{2}{l}{ Responders $^{*}$} & & \multicolumn{2}{l}{ Non-responders* } \\
\cline { 2 - 3 } \cline { 5 - 6 } & Men & Women & & Men & Women \\
\hline $10-19$ & 27 & 24 & 8 & 6 \\
$20-29$ & 11 & 19 & 12 & 9 \\
$30-39$ & 19 & 18 & & 8 & 5 \\
$40-49$ & 19 & 16 & & 5 & 6 \\
$\geqslant 50$ & 17 & 15 & 14 & 16 \\
Total & 93 & 92 & 47 & 42 \\
\hline
\end{tabular}

*Number of subjects in each age and sex group are given. (Chi-square = 18.86; $p=N S$ ).

age and sex distribution of responders and nonresponders. Results of blood pressure, anthropometric measurements, and urine analyses were available from 185 subjects. Thirteen of them were taking drugs known to reduce blood pressure and were excluded from further analysis. Their mean age was $54.3 \pm 3.4$ years (mean \pm standard deviation) and their blood pressure $143 \pm 5 / 82 \pm 3$ $\mathrm{mm} \mathrm{Hg}$. Their urinary excretion of cadmium and lead averaged $10 \cdot 0 \pm 1 \cdot 8 \mathrm{nmol} / 24 \mathrm{~h}$ and $59 \cdot 1 \pm 10 \cdot 0$ $\mathrm{nmol} / 24 \mathrm{~h}$, respectively. Twenty four hour urine collections are sometimes incorrect (incomplete or collected for more than 24 hours). The urinary creatinine excretion was therefore plotted against body weight in both sexes separately and subjects who fell outside the 2 standard deviation range of the regression lines were excluded. Altogether 162 24 hour urine collections were considered for analysis. Spot urine samples with $\mathrm{pH}$ equal to or higher than 5.5 were available for 143 of these 162 subjects, the other 19 being excluded since $\beta_{2}$ microglobulin undergoes proteolytic degradation when $\mathrm{pH}$ falls below $5 \cdot 5 .^{29}$

Student's $t$ test for unpaired data was used to compare group means. Blood pressure and other items were correlated with each other, using Pearson's correlation coefficients and significance levels, derived from two-tailed tests. To determine the independent effects of the anthropometric and urine measurements on blood pressure multiple regression equations were calculated, using a stepwise (stepup) procedure terminating when all regression 
coefficients were significant at the $5 \%$ level. Comparison of group means and regression analysis were performed after normalising the distributions of 24 hour urinary cadmium and lead and those of urinary $\boldsymbol{\beta}_{\mathbf{2}}$-microglobulin and retinol binding protein by a logarithmic transformation.

\section{Results}

\section{GENERAL CHARACTERISTICS OF THE PARTICIPANTS}

Table 2 shows the average age, blood pressure, and body weight, separately in youths (10-19 years) and adults ( $\geqslant 20$ years) of both sexes. The pulse rate was similar in the four age-sex groups and averaged 75 $\pm 10 \cdot 3$ beats $/ \mathrm{min}$ (range $51-110$ ).

\section{RESULTS OBTAINED FROM 24 HOUR URINE SAMPLES}

Table 3 shows the mean 24 hour excretion of the urinary constituents, together with their standard deviation and ranges. The figure illustrates the aver- age urinary cadmium and lead excretion for both sexes and five age groups. Over the age of 20 , the urinary cadmium and lead output was higher $(\mathrm{p}<$ 0.01 ) in male than female subjects (Table 3 ) and increased with age until age 50. The excretion of urinary cadmium and lead increased also with body weight, but this effect disappeared after adjusting for sex and age.

Twenty two male manual workers, aged 20 and over, had higher $(\mathrm{p}<0.05)$ average cadmium excretions than 35 male office workers of similar age $(12.6 \mathrm{nmol} / 24 \mathrm{~h} v 7.5 \mathrm{nmol} / 24 \mathrm{~h})$. This difference was not apparent for their urinary lead excretion (62 $\mathrm{nmol} / 24 \mathrm{~h}$ and $61 \mathrm{nmol} / 24 \mathrm{~h}$ respectively). Though at least four and possibly more of the manual workers were occupationally exposed to cadmium, the highest cadmium excretion encountered in this group was only $36 \cdot 5 \mathrm{nmol}$ per 24 hours, which is far less than the average in male workers with heavy cadmium exposure. ${ }^{28}$ Among men, the average 24 hour urinary excretion of cadmium and lead was not statistically different between 11 non-smokers and

Table 2 General characteristics of the male and female subjects

\begin{tabular}{|c|c|c|c|c|}
\hline & \multicolumn{2}{|c|}{ Adolescents (10-19 years) } & \multicolumn{2}{|c|}{ Adults $(\geqslant 20$ years $)$} \\
\hline & Boys & Girls & Men & Women \\
\hline $\begin{array}{l}\text { No } \\
\text { Age (years) }\end{array}$ & $\begin{array}{l}24 \\
14 \cdot 6 \pm 2 \cdot 86 \\
10-19\end{array}$ & $\begin{array}{c}22 \\
13 \cdot 5 \pm 2 \cdot 94 \\
10-19\end{array}$ & $\begin{array}{l}57 \\
41 \cdot 0 \pm 13 \cdot 50 \\
20-75\end{array}$ & $\begin{array}{c}59 \\
38 \cdot 7 \pm 13 \cdot 80 \\
20-80\end{array}$ \\
\hline Systolic pressure $(\mathrm{mm} \mathrm{Hg}$ ) & $122 \pm 14 \cdot 6$ & $115 \pm 12 \cdot 7$ & $131 \pm 10 \cdot 9$ & $128 \pm 15 \cdot 6$ \\
\hline & $99-149$ & $95-138$ & $111-167$ & $98-178$ \\
\hline Diastolic pressure $(\mathrm{mm} \mathrm{Hg})$ & $\begin{array}{l}61 \pm 8 \cdot 6 \\
48-81\end{array}$ & $62 \pm 6 \cdot 1$ & $\begin{array}{l}76 \pm 9 \cdot 5 \\
45-94\end{array}$ & $\begin{array}{l}76 \pm 8 \cdot 5 \\
55-94\end{array}$ \\
\hline Body weight (kg) & $\begin{array}{l}55 \cdot 1 \pm 15 \cdot 80 \\
33 \cdot 0-84 \cdot 8\end{array}$ & $\begin{array}{l}47 \cdot 0 \pm 9 \cdot 56 \\
30 \cdot 8-65 \cdot 0\end{array}$ & $\begin{array}{l}78 \cdot 2 \pm 12 \cdot 54 \\
51 \cdot 5-107 \cdot 3\end{array}$ & $\begin{array}{l}62 \cdot 8 \pm 10 \cdot 25 \\
44 \cdot 0-91 \cdot 0\end{array}$ \\
\hline
\end{tabular}

Values are arithmetic means \pm standard deviation; the range is also given.

Table 3 Results of the urine analyses in male and female subjects

\begin{tabular}{|c|c|c|c|c|}
\hline & \multicolumn{2}{|c|}{ Adolescents (10-19 years) } & \multicolumn{2}{|c|}{ Adults $(\geqslant 20$ years $)$} \\
\hline & Boys & Girls & Men & Women \\
\hline $\begin{array}{l}\text { No } \\
\text { Volume }(1 / 24 h)\end{array}$ & $\begin{array}{c}24 \\
1.06\end{array}$ & $\begin{array}{l}22 \\
0.82 \\
0.38-1.78\end{array}$ & $\begin{array}{r}57 \\
1 \cdot 55\end{array}$ & $\begin{array}{l}59 \\
1.33\end{array}$ \\
\hline Creatinine (mmol/24 h) & $\begin{array}{c}12 \cdot 5 \pm 4 \cdot 85 \\
5 \cdot 4-27 \cdot 1\end{array}$ & $\begin{array}{c}10 \cdot 8 \pm 2 \cdot 54 \\
7 \cdot 0-17 \cdot 2\end{array}$ & $\begin{array}{c}17.9 \pm 4.57 \\
6.4-28.6\end{array}$ & $\begin{array}{c}12 \cdot 3 \pm 3 \cdot 27 \\
5 \cdot 1-20 \cdot 2\end{array}$ \\
\hline Sodium $(\mathrm{mmol} / 24 \mathrm{~h})$ & $141 \pm 63 \cdot 2$ & $121 \pm 40 \cdot 8$ & $187 \pm 57 \cdot 9$ & $133 \pm 48 \cdot 9$ \\
\hline Potassium $(\mathrm{mmol} / 24 \mathrm{~h})$ & $\begin{array}{l}46 \pm 24 \cdot 9 \\
20-128\end{array}$ & $\begin{array}{l}63 \pm 22 \cdot 3 \\
35-139\end{array}$ & $\begin{array}{l}84-325 \\
70 \pm 22 \cdot 3 \\
25-164\end{array}$ & $\begin{array}{l}40-285 \\
20-117.8\end{array}$ \\
\hline Cadmium (nmol/24 h) & $\begin{array}{l}2.1 \pm 1.27 \\
0.4-5.4\end{array}$ & $\begin{array}{l}2 \cdot 7 \pm 2 \cdot 20 \\
0.9-11 \cdot 3\end{array}$ & $\begin{array}{l}9 \cdot 3 \pm 6 \cdot 82 \\
2 \cdot 0-36 \cdot 5\end{array}$ & $\begin{array}{l}7 \cdot 2 \pm 5 \cdot 00 \\
0.6-19.3\end{array}$ \\
\hline $\begin{array}{c}\log _{10} \text { distribution* } \\
\text { Lead (nmol/24 h) } \\
\log _{10} \text { distribution* }\end{array}$ & $\begin{array}{c}0.23 \pm 0.300 \\
32 \pm 21 \cdot 2 \\
2-86 \\
1 \cdot 40 \pm 0.347\end{array}$ & $\begin{array}{c}0 \cdot 34 \pm 0 \cdot 270 \\
23 \pm 11 \cdot 2 \\
10-59 \\
1 \cdot 33 \pm 0 \cdot 180\end{array}$ & $\begin{array}{c}0.88 \pm 0.284 \\
64 \pm 31 \cdot 4 \\
21-158 \\
1.75 \pm 0.215\end{array}$ & $\begin{array}{c}0.73 \pm 0.359 \\
40 \pm 22 \cdot 1 \\
7-99 \\
1.52 \pm 0.256\end{array}$ \\
\hline
\end{tabular}

Values are arithmetic means \pm standard deviation; the range is also given.

*For non-normal distributions the arithmetic mean and standard deviation obtained after logarithmical transformation are shown in addition. 

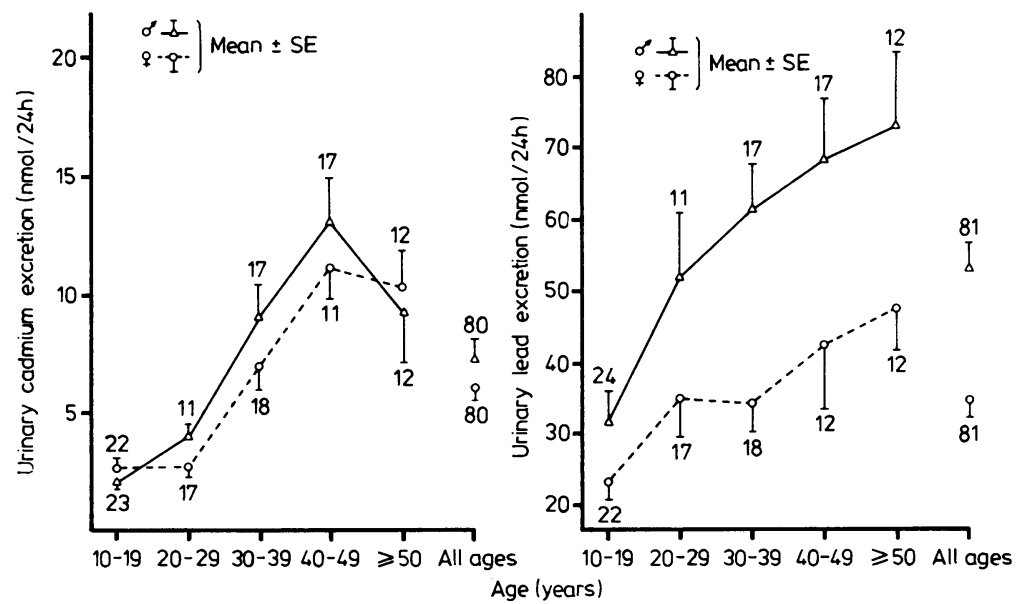

Twenty four hour urinary excretion of cadmium and lead, expressed in nanomoles (mean \pm standard error), according to age in male $(\Delta)$ and female $(O)$ subjects.

Number of subjects in each age group is given for both sexes.

46 smokers $(8.7 v 9.6 \mathrm{nmol} / 24 \mathrm{~h}$ cadmium and $61 v$ $65 \mathrm{nmol} / 24 \mathrm{~h}$ lead, respectively); also among women, 31 non-smokers and 28 smokers excreted similar amounts of cadmium and lead $(7.8 v 6.5$ $\mathrm{nmol} / 24 \mathrm{~h}$ cadmium and $37 v 41 \mathrm{nmol} / 24 \mathrm{~h}$ lead, respectively). Furthermore, the output of urinary cadmium was similar in present $(35$ men and 24 women) and past (11 men and 4 women) smokers, and remained independent of smoking habits when, in addition to sex, age and body weight were also taken into account.

RESULTS OBTAINED FROM SPOT URINE SAMPLES Table 4 gives the average concentration of urinary $\beta_{2}$-microglobulin and retinol binding protein for youths and adults of both sexes. Both the concentration of these light molecular weight proteins and the amount excreted per gram creatinine were independent of age and sex.

\section{CORRELATION BETWEEN BLOOD PRESSURE AND} URINARY CONSTITUENTS

Table 5 gives first order correlations between blood pressure and various other items. Systolic pressure in youths, diastolic in men, and both systolic and diastolic pressure in women were positively and significantly correlated with age and body weight. In women systolic and diastolic pressure were

Table 4 Results obtained from spot urine samples in male and female subjects

\begin{tabular}{|c|c|c|c|c|}
\hline & \multicolumn{2}{|c|}{ Adolescents (10-19 years) } & \multicolumn{2}{|c|}{ Adults $(\geqslant 20$ years $)$} \\
\hline & Boys & Girls & Men & Women \\
\hline 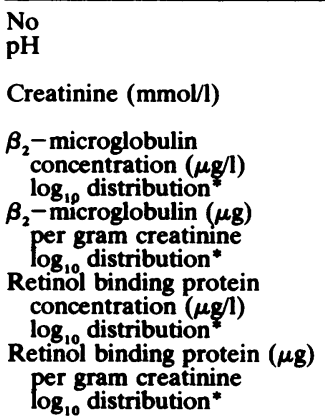 & $\begin{array}{c}24 \\
6 \cdot 7 \pm 0.58 \\
5 \cdot 8-8 \cdot 0 \\
11 \cdot 2 \pm 5 \cdot 49 \\
1 \cdot 6-20 \cdot 2 \\
110 \pm 77 \cdot 5 \\
7-323 \\
1 \cdot 91 \pm 0.390 \\
88 \pm 57 \cdot 9 \\
9-253 \\
1 \cdot 88 \pm 0.389 \\
56 \pm 40 \cdot 9 \\
13-202 \\
1.66 \pm 0.281 \\
50 \pm 33 \cdot 5 \\
19-160 \\
1.64 \pm 0.236\end{array}$ & $\begin{array}{c}21 \\
6 \cdot 5 \pm 0.67 \\
5 \cdot 5-7 \cdot 8 \\
10 \cdot 9 \pm 3 \cdot 82 \\
4 \cdot 0-17 \cdot 9 \\
75 \pm 36 \cdot 2 \\
4-126 \\
1 \cdot 79 \pm 0.347 \\
65 \pm 27 \cdot 9 \\
3-107 \\
1 \cdot 73 \pm 0.361 \\
51 \pm 53 \cdot 6 \\
5-240 \\
1 \cdot 55 \pm 0.393 \\
39 \pm 32 \cdot 2 \\
5-157 \\
1 \cdot 49 \pm 0.300\end{array}$ & $\begin{array}{c}52 \\
6 \cdot 3 \pm 0 \cdot 62 \\
5 \cdot 5-7 \cdot 6 \\
12 \cdot 6 \pm 5 \cdot 53 \\
2 \cdot 0-26 \cdot 8 \\
90 \pm 72 \cdot 5 \\
6-353 \\
1 \cdot 80 \pm 0 \cdot 414 \\
67 \pm 49 \cdot 1 \\
4-263 \\
1 \cdot 70 \pm 0.373 \\
59 \pm 34 \cdot 5 \\
10-164 \\
1 \cdot 69 \pm 0.304 \\
45 \pm 22 \cdot 0 \\
7-118 \\
1 \cdot 59 \pm 0.257\end{array}$ & $\begin{array}{c}46 \\
6 \cdot 5 \pm 0.75 \\
5 \cdot 5-9 \cdot 4 \\
11 \cdot 4 \pm 5 \cdot 7 \\
1 \cdot 8-27 \cdot 9 \\
84 \pm 53 \cdot 9 \\
14-240 \\
1 \cdot 83 \pm 0.312 \\
72 \pm 36 \cdot 6 \\
8-170 \\
1 \cdot 79 \pm 0.285 \\
61 \pm 50 \cdot 4 \\
11-253 \\
1 \cdot 65 \pm 0.341 \\
51 \pm 32 \cdot 0 \\
11-169 \\
1.62 \pm 0.275\end{array}$ \\
\hline
\end{tabular}

Values are arithmetic means \pm standard deviation; the range is also given.

*For non-normal distributions the arithmetic mean and standard deviation obtained after logarithmical transformation are also shown. 
significantly and positively related to the 24 hour urinary cadmium excretion and diastolic pressure significantly but negatively to the urinary $\beta_{2-}$ microglobulin concentration.

The results of stepwise (stepup) multiple regression of blood pressure on different variables are summarised in table 6 . The explanatory variables included: age, square of age, body weight, pulse rate, smoking habit, the 24 hour urinary constituents, and urinary $\beta_{2}$-microglobulin and retinol binding protein (expressed in $\mu \mathrm{g} / \mathrm{l}$ and in $\mu \mathrm{g} / \mathrm{g}$ creatinine). In youths there was a positive association only between blood pressure and body weight. In men multivariate analysis confirmed a significant and negative relation between systolic pressure and 24 hour urinary potassium as previously reported in this population..$^{30}{ }^{31}$ After adjusting for age, diastolic pressure was significantly and negatively related to 24 hour urinary cadmium in men. The $t$-value for the partial regression coefficient was -2.04 $(\mathrm{p}=0.047)$, whereas the corresponding $t$-value for entering potassium instead of cadmium just failed to reach statistical significance $(t=-1 \cdot 80 ; p=0.077)$. After adjusting for age, present smoking habit, and urinary $\beta_{2}$-microglobulin a weak $(t=-2 \cdot 21$; $\mathrm{p}=0.033$ ) but negative correlation became apparent between systolic pressure and urinary cadmium in women. In women the urinary $\beta_{2}$-microglobulin concentration was also negatively and independently related to both systolic $(t=-2.75$; $\mathrm{p}=0.009)$ and diastolic $(t=-3.07 ; \mathrm{p}=0.004)$ pressure, whereas in men there was no such relation with systolic ( $t$ to enter $\beta_{2}$-microglobulin concentration $=0.31 ; \mathrm{p}=0.758)$ nor with diastolic $(t=$ $-0.55 ; p=0.588$ ) pressure.

There was no significant and independent contribution of 24 hour urinary lead to blood pressure in any of the age-sex groups and the same was true for urinary retinol binding protein.

\section{Discussion}

The present study aimed to determine the excretion of urinary cadmium and lead in a random sample of

Table 5 First order correlation coefficients between systolic $(S B P)$ and diastolic $(D B P)$ blood pressure and different variables

\begin{tabular}{|c|c|c|c|c|c|c|}
\hline & \multicolumn{2}{|c|}{ Adolescents } & \multicolumn{2}{|c|}{ Adult men } & \multicolumn{2}{|c|}{ Adult women } \\
\hline & $S B P$ & $D B P$ & $S B P$ & $D B P$ & $S B P$ & $D B P$ \\
\hline $\begin{array}{l}\text { Age } \\
\text { Body weight } \\
\log _{10} 24-\mathrm{h} \text { cadmium } \\
\log _{10} \text { 24-h lead } \\
24-h \text { potassium } \\
\log _{10} \beta_{2}-\mathrm{m} \text { concentration }(\mu \mathrm{g} / \mathrm{l}) \\
\log _{10} \beta_{2}-\mathrm{m}(\mu \mathrm{g}) \text { per gram creatinine } \\
\log _{10} \text { RBP concentration }(\mu \mathrm{g} / \mathrm{l}) \\
\log _{10} \text { RBP }(\mu \mathrm{g}) \text { per gram creatinine }\end{array}$ & $\begin{array}{l}+0.56^{* * *} \\
+0.78^{* * *} \\
+0.11 \\
+0.01 \\
+0.11 \\
-0.07 \\
-0.01 \\
+0.11 \\
+0.18\end{array}$ & $\begin{array}{l}+0.16 \\
+0.37^{*} \\
+0.03 \\
+0.03 \\
-0.02 \\
-0.16 \\
-0.21 \\
+0.07 \\
-0.04\end{array}$ & $\begin{array}{l}+0.15 \\
-0.10 \\
-0.02 \\
-0.19 \\
-0.27^{*} \\
-0.01 \\
-0.04 \\
+0.03 \\
+0.05\end{array}$ & $\begin{array}{l}+0.45^{* * *} \\
+0.38^{* *} \\
+0.18 \\
+0.07 \\
-0.18 \\
+0.01 \\
+0.05 \\
-0.05 \\
-0.02\end{array}$ & $\begin{array}{l}+0.65^{* * *} \\
+0.40^{* * *} \\
+0.30^{*} \\
+0.06 \\
-0.08 \\
-0.28 \\
-0.15 \\
-0.05 \\
+0.14\end{array}$ & $\begin{array}{l}+0.45^{* * *} \\
+0.39^{* *} \\
+0.38^{* *} \\
+0.08 \\
+0.04 \\
-0.44^{* *} \\
-0.17 \\
-0.15 \\
+0.12\end{array}$ \\
\hline
\end{tabular}

Significance of the correlation coefficients: ${ }^{*} \mathrm{p}<0.05 ;{ }^{* *} \mathrm{p}<0.01$ and ${ }^{* * *} \mathrm{p}<0.001$.

$\beta_{2}-m=\beta_{2}$-microglobulin. RBP $=$ Retinol binding protein.

Table 6 Results of multiple regression of systolic (SBP) and diastolic (DBP) blood pressure and different variables

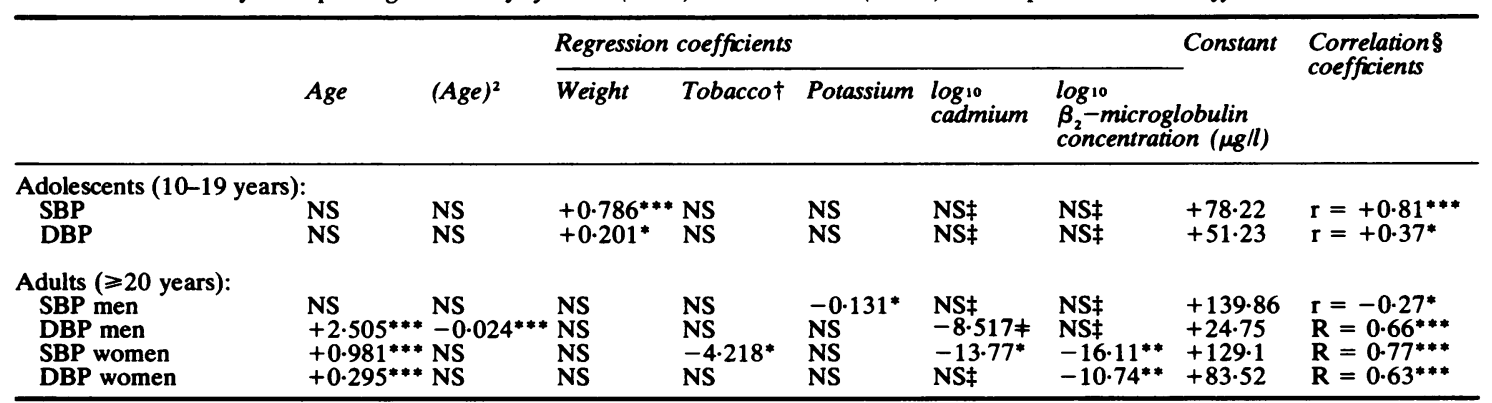

$\S$ Simple (r) or multiple (R) correlation coefficients obtained as a result of stepwise (stepup) regression analysis.

+ Coded as follows: +1 present-smokers; -1 past-smokers and non-smokers.

* $\mathrm{p}<0.05: * * \mathrm{p}<0.01$; and ${ }^{* * *} \mathrm{p}<0.001 ; \mathrm{NS}=$ Not significant and therefore not included in the multiple regression equation.

$\neq t$ to enter $\log _{10}$ cadmium $=-2.04(p=0.047) ; t$ to enter urinary potassium instead $=-1.80(p=0.077)$.

$\ddagger+0.28>t$ to enter $>-1 \cdot 01(p>0 \cdot 3)$. 
the population of a Belgian town and to investigate whether the urinary elimination of these metals was in any way related to blood pressure.

\section{URINARY CADMIUM EXCRETION}

In accordance with previous reports ${ }^{13233}$ the urinary cadmium excretion increased with advancing age and was higher in men than women. When age and sex were taken into account urinary cadmium was not dependent on body weight. Expressed per gram creatinine, the urinary output of cadmium averaged $0.21 \mu \mathrm{g}$ in youths, 0.54 in men, and $0.62 \mu \mathrm{g}$ in women. The small amounts of cadmium and lead excreted in the urine in the present population are compatible with a low average exposure. In middle aged male workers living in Belgium but without professional exposure Bernard et al found an average cadmium excretion of $0.82 \mu \mathrm{g} / \mathrm{g}$ creatinine. ${ }^{28}$ Other investigators estimated the output of urinary cadmium to be $1.25 \mu \mathrm{g} / \mathrm{g}$ creatinine in adults ${ }^{23}$ and $2 \cdot 1 \mu \mathrm{g} /$ day in hypertensive men and women. ${ }^{21}$

The average urinary cadmium excretion observed in the present study was similar to that found in non-occupationally exposed subjects with a daily dietary cadmium intake of about $15 \mu \mathrm{g},{ }^{32}{ }^{33}$ which is in agreement with the median value $(15 \mu \mathrm{g} / 24 \mathrm{~h})$ reported in a recent duplicate meal study in the Belgian population..$^{34}$ It should not be forgotten, however, that since cadmium is a highly cumulative metal, which is preferentially concentrated in the kidney, urinary excretion is more a reflection of an individual's life time exposure and body burden than of day to day variations in intake. This explains why the elimination of urinary cadmium increases with advancing age. In the older age groups ( $\geqslant 50$ years) the urinary cadmium excretion seems to level off but the reason for this is not clear unless levels of exposure have increased in more recent generations.

In the present study no difference in urinary cadmium output could be shown between non-smokers, present smokers, and past smokers. Though there is general consensus that tissue ${ }^{18-2035}$ and blood ${ }^{622}$ concentrations of cadmium are raised in smokers, studies on urinary cadmium have either not taken into account cigarette consumption ${ }^{2123}$ or have failed to show any significant correlation with smoking. ${ }^{19}$ In the postmortem studies of Lewis and coworkers, ${ }^{35}$ and in a recent WHO survey ${ }^{36}$ the tissue concentrations of cadmium showed considerable overlap between smokers and non-smokers and, in multiple regression analysis, were related to moderate and heavy but not to light (less than one pack a day) smoking. ${ }^{35}$ In the present study only $25 \%$ of the smokers consumed more than one pack a day, and this may explain the absence of any significant relation between 24 hour urinary cadmium output and smoking habit. The negative correlation observed in women between systolic pressure and present cigarette consumption is in accordance with previous experience. ${ }^{37}$

The work environment, if polluted by cadmium, may constitute a major source of body cadmium. Male manual workers had a greater 24 hour cadmium output than men with other occupations. Nevertheless, urinary $\beta_{2}$-microglobulin and retinol binding protein frequently used for biological monitoring of exposed workers were not significantly related to the urinary elimination of cadmium and lead in the present population, which had a low average exposure.

\section{URINARY LEAD EXCRETION}

In the present population with low average exposure, urinary lead excretion increased with age and was higher in men than women. Body weight, occupation, and tobacco consumption did not influence the amount of lead excreted in the urine. Expressing urinary lead output per gram creatinine eliminated the differences between sexes $(6.9 \mu \mathrm{g}$ in men $v 6.0$ $\mu \mathrm{g}$ in women) but not between the various age groups (4.5 $\mu \mathrm{g}$ in youths $v 6.5 \mu \mathrm{g}$ in adults). In middle aged Belgian workers with no occupational exposure urinary lead excretion is $14 \mu \mathrm{g}$ lead/g creatinine $^{28}$; in unexposed Italian workers it is $29 \mu \mathrm{g}$ $124 \mathbf{h}^{38}$ whereas in Czechoslovakia an average urinary concentration of $52 \mu \mathrm{g} / 1$ is found. ${ }^{39}$ The greater urinary lead output in men as compared with women is in accordance with other reports where men have also been shown to have higher blood concentrations. ${ }^{40}$

\section{BLOOD PRESSURE AND URINARY CADMIUM AND LEAD EXCRETION}

First order regression analysis showed a positive correlation between blood pressure and urinary cadmium in women. After adjusting for other contributing variables, however, a weak but negative correlation became apparent between systolic pressure and urinary cadmium indicating that a higher cadmium excretion was associated with a lower systolic pressure. In men there was an independent and inverse relation between diastolic pressure and urinary cadmium; taking age into account, a higher urinary cadmium excretion was found to be associated with a lower diastolic pressure. These correlations between blood pressure and urinary cadmium do not necessarily imply a causal relationship, since an unknown third factor might be the common link which produces the association. The association could also be explained by the hypothesis that subjects with a higher blood pressure are less able to eliminate cadmium in their urine. Finally, these cor- 
relations could indicate that cadmium, even at its usual environmental concentration, might have some sort of biological action and, for unknown reasons, lower blood pressure. Initially a positive association has been found between the prevalence of high blood pressure and the cadmium content of both drinking water ${ }^{8}$ and ambient air. ${ }^{7}$ The relation between arterial pressure and renal tissue levels of cadmium has been reported to be positive, ${ }^{10}$ nonexistent, ${ }^{16-182035}$ and negative, ${ }^{19}$ whereas the positive correlation observed in some studies ${ }^{11-14}$ between arterial pressure and blood concentrations of cadmium could not be confirmed by other investigators. ${ }^{622}$ Looking more specifically at urinary cadmium, most researchers ${ }^{21} 23$ were unable to show any significant relationship with blood pressure. Confounding by age, sex distribution, and cigarette consumption may at least account for part of the controversy. Genetic susceptibility and duration of exposure $^{41}$ could also be important determinants of the pressure response to cadmium and are likely to differ in the various populations studied. Furthermore, as new techniques became available, more recent studies have used improved methods for measuring trace metals in body fluids and tissues. Finally, the association between cadmium and blood pressure could be more complex than a simple linear relationship, since recent animal experiments have shown a bell shaped dose response curve between blood pressure and exposure to cadmium. ${ }^{42}$

By contrast with cadmium, urinary lead did not contribute to the blood pressure variability in any of the age-sex groups of the present study. Among subjects with excessive lead exposure the prevalence of hypertension and cerebrovascular disease has been variously reported to be increased ${ }^{3}$ or not affected ${ }^{24}$ whereas Beevers et al have shown a positive relation between arterial pressure and blood lead concentrations. ${ }^{56}$ Boscolo et al looking at urinary lead as an index of long term exposure found a positive association with arterial pressure. ${ }^{15}$

A striking but unexplained observation is the negative and independent relation found in women between blood pressure and urinary $\boldsymbol{\beta}_{2}$ microglobulin. This correlation indicated that higher blood pressure levels were associated with a lower urinary $\beta_{2}$-microglobulin concentration. Light molecular weight proteins such as $\beta_{2}$-microglobulin and retinol binding protein pass readily through the glomerular barrier but are subsequently almost totally reabsorbed in the proximal tubule. ${ }^{29}$ There was, however, no correlation between blood pressure and urinary retinol binding protein. It is unlikely, therefore, that the present relation between arterial pressure and urinary $\beta_{2}$-microglobulin in women can be explained by a renal mechanism.
On the other hand, it is not clear how a higher blood pressure could be related to decreased endogenous synthesis of $\beta_{2}$-microglobulin. $\beta_{2}$-Microglobulin being an integral part of the histocompatibility antigens $^{29}$ could be considered to be some sort of a genetic marker, but why should it also be related to blood pressure in women?

\section{Appendix}

\section{CONVERSION OF UNITS}

$\begin{array}{ll}\text { Cadmium } & 1 \mathrm{nmol}=112.4 \mathrm{ng} . \\ \text { Lead } & 1 \mathrm{nmol}=207 \cdot 1 \mathrm{ng} . \\ \text { Sodium } & 1 \mathrm{mmol}=23.0 \mathrm{mg} . \\ \text { Potassium } & 1 \mathrm{mmol}=39 \cdot 1 \mathrm{mg} . \\ \text { Creatinine } & 1 \mathrm{mmol}=113.1 \mathrm{mg} .\end{array}$

This study was made possible through the cooperation of the general practitioners and the Belgian Red Cross at Hechtel-Eksel.

Twenty four hour urine samples were analysed for electrolytes and creatinine in the Central Laboratory of the University Hospital St Rafaël, Leuven, Belgium, under supervision of Professor $\mathbf{J}$ H Claes and $\mathrm{Dr} \mathrm{W}$ Lissens. Mr Grauwels performed the computer analysis. Expert clerical and technical help was provided by Mrs V Mariën, Mrs M Stinissen, Mrs Y Toremans, and Mrs N Vangeel.

This study has been partially supported by grants of the Belgian Research Institutes "Nationaal Fonds voor Wetenschappelijk Onderzoek," "Instituut voor Wetenschappelijk Onderzoek in Nijverheid en Landbouw," and "Fond National de la Recherche Scientifique Médicale," and by a grant from the "Algeméne Spaar- en Lijfrentekas."

\section{References}

${ }^{1}$ Lauwerys R. Cadmium in man. In: Webb $\mathbf{M}$ ed. Chemistry, biochemistry and biology of cadmium. Amsterdam: Elsevier/ North-Holland Biomedical Press, 1979;433-55.

2 Schroeder HA. Cadmium as a factor in hypertension. J Chronic Dis 1965;18:647-56.

${ }^{3}$ Dingwall-Fordyce I, Lane RE. A follow-up study of lead workers. Br J Ind Med 1963;20:313-5.

4 Crawford MD, Clayton DG. Lead in bones and drinking water in towns with hard and soft water. Br Med J 1973;ii:21-3.

5 Beevers DG, Erskine E, Robertson M, et al. Blood-lead and hypertension. Lancet 1976;i:1-3.

- Beevers DG, Cruickshank JK, Yeoman WB, Carter GF, Goldberg A, Moore MR. Blood-lead and cadmium in human hypertension. J Environ Pathol Toxicol 1980;4:251-60.

${ }^{7}$ Carroll RE. The relationship of cadmium in the air to cardiovascular disease death rates. JAMA 1966;198:177-9.

${ }^{8}$ Bierenbaum ML, Fleischman AI, Dunn J, Arnold J. Possible toxic water factor in coronary heart disease. Lancet 1975; i: $1008-10$.

${ }^{9}$ Carruthers M, Smith B. Evidence of cadmium toxicity in a population living in a zinc-mining area: pilot survey of Shipham residents. Lancet $1979 ; \mathrm{i}: 845-7$. 
${ }^{10}$ Lener J, Bibr B. Cadmium and hypertension. Lancet 1971;i:970.

"Glauser SC, Bello CT, Glauser EM. Blood-cadmium levels in normotensive and untreated hypertensive humans. Lancet 1976;i:717-8.

12 Thind GS, Fisher GM. Plasma cadmium and zinc in human hypertension. Clinical Science Molecular Medicine 1976;51:483-6.

${ }^{13}$ Khera AK, Wibberley DG, Edwards KW, Waldron HA. Cadmium and lead levels in blood and urine in a series of cardiovascular and normotensive patients. International Journal of Environmental Studies 1980;14:309-12.

${ }^{14}$ Revis NW, Zinsmeister AR. The relationship of blood cadmium level to hypertension and plasma norepinephrine level: a Romanian study. Proc Soc Exp Biol Med 1981;167:254-60.

is Boscolo P, Galli G, Iannaccone A, Martino F, Porcelli G, Troncone $\mathbf{L}$. Plasma renin activity and urinary kallikrein excretion in lead-exposed workers as related to hypertension and nephropathv. Life Sci 1980:28:175-84.

${ }^{16}$ Morgan JM. "Normal" lead and cadmium content of the human kidney. Arch Environ Health 1972;24:364-8.

${ }^{17}$ Hine $\mathbf{C H}$, Wright $\mathbf{J}$, Goodman D. Tissue levels of cadmium in different disease states. Toxicol Appl Pharmacol 1973;25:476-7.

${ }^{18}$ McKenzie JM. Tissue concentration of cadmium, zinc and copper from autopsy samples. NZ Med J 1974;79:1016-9.

$19 \emptyset$ stergaard K. Cadmium and hypertension. Lancet 1977;i:6778.

${ }^{20}$ Cummins PE, Dutton J, Evans CJ, Morgan WD, Sivyer A, Elwood PC. An in-vivo study of renal cadmium and hypertension. Eur J Clin Invest 1980;10:459-61.

${ }^{21}$ Wester PO. Trace elements in serum and urine from hypertensive patients before and during treatment with chlorthalidone. Acta Med Scand 1973;194:505-12.

${ }^{22}$ Beevers DG, Campbell BC, Goldberg A, Moore MR, Hawthorne VM. Blood-cadmium in hypertensives and normotensives. Lancet 1976;ii:1222-4.

${ }^{23}$ Szadkowski D, Schaller K-H, Lehnert G. Renale Cadmiumausscheidung, Lebensalter und arterieller Blutdruck. Zeitschrift für Klinische Chemie und Klinische Biochemie 1969;7:551-2.

${ }^{24}$ Cramér K, Dahlberg $\mathbf{L}$. Incidence of hypertension among lead workers: a follow-up study based on regular control over 20 years. Br J Ind Med 1966;23:101-4.

${ }^{25}$ Roels H, Buchet JP, Lauwerys R, et al. Lead and cadmium absorption among children near a non-ferrous metal plant. A follow-up study of a test case. Environ Res 1978;15:290-308.

${ }^{26}$ Bernard A, Vyskozil A, Lauwerys R. Determination of $\beta_{2}$ microglobulin in human urine and serum by latex immunoassay. Clin Chem 1981;27:832-7.

${ }^{27}$ Bernard A, Moreau D, Lauwerys R. Latex immunoassay of retinol binding protein. Clin Chem 1982;28:1167-71.
${ }^{28}$ Bernard A, Buchet JP, Roels H, Masson P, Lauwerys R. Renal excretion of proteins and enzymes in workers exposed to cadmium. Eur J Clin Invest 1979;9:11-22.

${ }^{29}$ Karlsson FA, Wibell L, Evrin PE. $\beta_{2}$-microglobulin in clinical medicine. Scand J Clin Lab Invest 1980;40, suppl 154:27-37.

${ }^{30}$ Staessen J, Fagard R, Lijnen P, Amery A, Bulpitt C, Joossens JV. Salt and blood pressure in Belgium.J Epidemiol Community Health 1981;35:256-61.

${ }^{31}$ Staessen J, Bulpitt C, Fagard R, Joossens JV, Lijnen P, Amery A. Four urinary cations and blood pressure-a population study in two Belgian towns. Am J Epidemiol 1983;117:67687.

${ }^{32}$ Elinder CG, Kjellström T, Linnman L, Pershagen G. Urinary excretion of cadmium and zinc among persons from Sweden. Environ Research 1978;15:473-84.

${ }^{33}$ Kowal NE, Johnson DE, Kraemer DF, Pahren HR. Normal levels of cadmium in diet, urine, blood and tissues of inhabitants of the United States. J Toxicol Environ Health 1979;5:995-1014.

${ }^{34}$ Buchet JP, Lauwerys R, Vandevoorde A, Pycke JM. Oral daily intake of cadmium, lead, manganese, copper, chromium, mercury, calcium, zinc, and arsenic in Belgium: a duplicate meal study. Food Chem Toxicol (in press).

${ }^{35}$ Lewis PG, Jusko WJ, Coughlin LL, Hartz S. Cadmium accumulation in man: influence of smoking, occupation, alcoholic habit and disease. J Chronic Dis 1972;25:717-26.

${ }^{36}$ Vahter M, ed. Assessment of human exposure to lead and cadmium through biological monitoring. Stockholm: Swedish Institute of Environmental Health and Karolinska Institute, 1982.

${ }^{37}$ Dawber TR, Kannel WB, Kagan A, Donabedian RK, McNamara PM, Pearson G. Environmental factors in hypertension. In: Stamler J, Stamler R, Pullman T, eds. The epidemiology of hypertension. New York: Grune and Stratton, 1967:255-88.

${ }^{38}$ Boscolo P, Salimei E, Adamo A, Porcelli G. Effects of environmental lead levels on the urinary kallikrein excretion of exposed workers. Life Sci 1977;20:1715-22.

${ }^{39}$ Chmielnicka J, Komsta-Szumska E, Szymanska JA. Arginase and kallikrein activities as biochemical indices of occupational exposure to lead. $\mathrm{Br} \mathrm{J}$ Ind Med 1981;38:175-8.

${ }^{40}$ Mahaffey KR, Annest JL, Roberts J, Murphy RS. National estimates of blood lead levels: United States, 1976-1980. N Engl $J$ Med 1982;307:573-9.

${ }^{41}$ Eakin DJ, Schroeder LA, Whanger PD, Weswig PH. Cadmium and nickel influence on blood pressure plasma renin and tissue mineral concentrations. Am J Physiol 1980;238:E53-E61.

${ }^{42}$ Kopp SJ, Glonek T, Perry HM, Erlanger M, Perry EF. Cardiovascular actions of cadmium at environmental exposure levels. Science 1982;217:837-9. 